\title{
Constitutional Right to Health Protection and Medical Care in Ukraine in the Context of the Pandemic COVID-19
}

\author{
Yurii Nikitin ${ }^{1}$, Valentyn Zolka², Mykhailo Korol ${ }^{2}$, Yaroslav Kushnir ${ }^{2}$ \& Nadiia Demchyk ${ }^{2}$ \\ ${ }^{1}$ Departments of the Educational-Scientific Institute of Law Criminal Law and Criminology, University of the \\ State Fiscal Servise of Ukraine, Irpin, Ukraine \\ ${ }^{2}$ Department of Constitutional, Administrative and International Law, National Academy of the State Border \\ Guard Service of Ukraine, Khmelnitskiy, Ukraine \\ Correspondence: Valentyn Zolka, National Academy of the State Border Guard Service of Ukraine, Kyiv, Ukraine. \\ E-mail:vz070779@gmail.com
}

Received: August 20, 2020

Accepted: September 17, 2020

Online Published: October 13, 2020

doi:10.5539/jpl.v13n4p99

URL: https://doi.org/10.5539/jpl.v13n4p99

\begin{abstract}
The content of the right to health protection and medical care according to Ukrainian legislation is analyzed in the article as well as peculiarities of its realisation in the context of the pandemic COVID-19. It examines also the correlation between the notion "health protection" and "medical care". On the basis of this correlation, the conclusion is made that the right to health protection is broader and includes, but is not limited to, the right to medical care. Some international standards in the sphere of health protection, which constitute the basis of Ukrainian legislation in this area, are analyzed.

The conclusion is made that Ukraine should take into account such standards while limiting human rights, in particular, the right to health protection and medical care in the context of the pandemic COVID-19. It is mentioned that the significant problem remains the legal regulation of quality control of medical care, the creation of organizational technologies with a clear division of control functions between the various actors in the health care system, which is extremely important in terms of the pandemic.

The attention is also paid to the personal data protection issue in the sphere of health care. The conclusion is drawn that there should be mechanisms for reporting and protecting against abuse while collecting personal data, and people should be able to challenge any COVID-19-related measures for the collection, aggregation, storage and further use of their data.
\end{abstract}

Keywords: human rights, health protection, medical care, personal data protection, pandemic COVID-19

\section{Introduction}

In Ukraine, the consequences of declaring a pandemic of the coronavirus COVID-19 became noticeable after March 11, 2020, when the authorities began to actively implement quarantine measures aimed at the maximum possible isolation of everyone (under "quarantine" here we understand "an enforced isolation or restriction of free movement imposed upon a vehicle, person, or material suspected of carrying a contagious disease for a certain period of time to prevent the spread of contagious disease"1).

Thus, in accordance with the Resolution of the Cabinet of Ministers of Ukraine of March 11, 2020 "On Prevention of the Spread of Acute Respiratory Disease Covid-19 Caused by the Coronavirus SARS-CoV-2 on the Territory of Ukraine" 2 it was decided to establish quarantine throughout Ukraine. A wide various of restrictions were implemented, such as prohibition of visits to educational institutions by its applicants and holding all mass events in which a certain number of persons take part, except for the measures necessary to ensure the work of state authorities and local governments. The authorities also adopted a number of decisions to restrict the operation of checkpoints and introduced new approaches and sanctions to prosecute individuals for violating quarantine

\footnotetext{
${ }^{1}$ USLegal. (2020). Quarantine Law and Legal Definition. [online] Available at: https://definitions.uslegal.com/q/quarantine/ [Accessed 27 Aug. 2020].

${ }^{2}$ Cabinet of Ministers of Ukraine. (2020). On prevention of the spread of acute respiratory disease COVID-19 caused by coronavirus SARS$\mathrm{CoV}-2$ on the territory of Ukraine: Resolution of the Cabinet of Ministers of Ukraine of March 11, 2020. [online] Available at: https://zakon.rada.gov.ua/laws/show/211-2020-\%D0\%BF\#Text [Accessed 15 Aug. 2020].
} 
measures.

When we talk about such special regimes in the state as quarantine or emergency, we must understand that these regimes are provided mainly by restricting fundamental human rights. Therefore, in these periods, it is more important than ever to assess the state's actions to interfere in human rights: how reasonable, necessary they are, and whether they really pursue the goal of protection.

The analysis of all the restrictions imposed during the quarantine period in Ukraine, reveals that some constitutional rights of citizens of Ukraine and persons staying in its territory have been most violated. Such rights include, in particular, the right to health protection and access to medical care, as planned hospitalizations and routine operations, other than urgent, have been suspended.

It should be noted that the legal regulation of access to medical care in Ukraine is still imperfect, although the medical reform is being held. Many problems remain in this area, which became particularly acute during the pandemic. Therefore, it is necessary to highlight the issues related to the implementation and protection of this right.

\section{Material Studied, Area Descriptions, Methods}

Problematic aspects of realization and protection of the constitutional rights of citizens to health protection and medical care, their legal support, were considered by many scholars, such as R. Stefanchuk ${ }^{3}$, O. Punda ${ }^{4}, V$. Bigun ${ }^{5}$, I. Senyuta ${ }^{6}$, S. Buletsa ${ }^{7}$, S.L. Greer $\&$ T. Sokol ${ }^{8}$ and others. These scientific achievements lie in the field of research in terms of the science of civil law, administrative law, social security law, however, today there is still a lack of research to ensure the protection of human and civil rights to health care in terms of constitutional law.

Considering that fact, it is extremely important to continue investigations in the sphere of health protection, to ensure proper realization of constitutional right to health protection and medical care. Such investigations are becoming even more important in the context of the pandemic COVID-19.

The study used general scientific and special methods to clarify the nature and peculiarities of realization of rights to health protection and medical care, as well as the principles of their regulation in legislation of Ukraine.

The historical-legal method was used in the study of the development and trends of legislation in the medical field in Ukraine an abroad.

Using a comparative legal method, an analysis of the legislation of Ukraine and other countries in the field of health protection and medical care was made.

The formal-logical method made it possible to identify contradictions and gaps in the current legislation governing relations in the research area. Thanks to this method, the concept of the right to health protection and medical care as well as principles of their protection and realization were defined.

\section{Results and Discussion}

\subsection{The Definition and Content of the Constitutional Human Right to Health Protection and Medical Care under the Legislation of Ukraine}

Life and health have always been and are the most important values, the neglect of which leads to irreversible consequences. The human right to health and medical care is a social right, the loss of which diminishes the value of many other goods and values. Human rights in the field of health protection are a broad institution, as it includes the mutual rights and responsibilities of the state and the citizen.

The Constitution of Ukraine in Article 3 declares that life and health, honor and dignity, inviolability and human

\footnotetext{
${ }^{3}$ Stefanchuk R. (2005). Civil Law of Ukraine. Kyiv: Pretsedent, 2005, p. 24

${ }^{4}$ Punda O. (2003). The concept and content of the right to health. "Bulletin of the Khmelnytsky Institute of Regional Management and Law", 3-4, p. 82

5 Bihun V. (2009). Judicial understanding of law in the mechanism of human rights. [online] Available at: http://bihun.in.ua/jushits/jurhit/article/632/

${ }^{6}$ Senyuta I. (2009). Patients' rights in the decisions of the European Court of Human Rights. Visnyk of Lviv National University, 48, p. 1320

${ }^{7}$ Buletsa S. (2015). Civil law relations in the field of medical activity: problems of theory and practice, Uzhgorod: Lira, 2015 , p. 72.

${ }^{8}$ Greer S.L. \& Sokol T. (2014). Rules for Rights: European Law, Health Care and Social Citizenship. "European law journal”, 20(1), pp. 6687. DOI: $10.1111 /$ eulj.12036
} 
security are the highest social values ${ }^{9}$. This constitutional provision defines health as the value and the primary and initial precondition for the life of every human being. Therefore, from the numerous rights provided by the Constitution of Ukraine, we can single out the human right to health care as a right that guarantees its physical existence and is a condition for ensuring the exercise of all other human rights.

According to Art. 49 of the Constitution of Ukraine, everyone has the right to health protection, medical care and medical insurance ${ }^{10}$. However, during the years of Ukraine's independence, these rights remain more declarative, despite the fact that the health care system has been in a state of reform for more than three years, and the health of the country's population is extremely low.

The Ukrainian doctrine has different views and positions on the definition of the human right to health. Thus, according to R. Stefanchuk, the right to health is a subjective right of individuals, which arises in relation to health as an intangible good and provides possession, use, disposal of this good, as well as its legal protection ${ }^{11}$. O. Punda believes that the right to health can be defined as a personal non-property right of an individual, a set of various powers related to the regulation of relations for the consumption of such non-material good as health, which can be realized by a person himself or with the help of others ${ }^{12}$. But no matter what definitions scientists give, the human right to health is an absolute inalienable right from birth. It occupies a leading place in the entire system of personal human rights ${ }^{13}$. In addition to various approaches to the interpretation of the definition of "human right to health" and discussions on the legal correctness of the use of this term, the issue of ensuring such a right is relevant. According to V. Bihun, to ensure human rights means to create conditions under which they are respected and recognized by both the state and the individual, as well as effectively implemented, if necessary, protected by law ${ }^{14}$.

As for the concept of "medical care", it is used both in Article 49 of the Constitution of Ukraine and in the preamble of many articles of the Fundamentals of the Legislation of Ukraine on Health Care ${ }^{15}$. Both scientists ${ }^{16}$ and practitioners $^{17}$ agree that the Fundamentals of the Legislation of Ukraine on Health Care determine the main components of medical care: emergency medical care, primary care, secondary care (specialized), tertiary care (highly specialized), palliative and medical rehabilitation, etc.).

The Resolution of the Cabinet of Ministers of Ukraine of July 11, 2002 "On Approval of the Program for Providing Citizens with State-Guaranteed Free Medical Care" states that medical care is an activity that includes a set of measures aimed at rehabilitation and treatment of patients in the provision threatens life, health and ability to work and is carried out by professionally trained workers who have the right to carry out this activity in accordance with the law ${ }^{18}$. However, this definition has been criticized by scholars as not meeting international standards. According to S. Antonov, rehabilitation measures cannot be used in case of threat to life and health, as they perform a restorative function in the rehabilitation of the patient, which is the next stage of the medical process (after the treatment process $)^{19}$.

The Fundamentals of the Legislation of Ukraine on Health Care provides the following definition: "medical care is the activity of professionally trained medical workers aimed at prevention, diagnosis, treatment and rehabilitation in connection with diseases, injuries, poisonings and pathological conditions, as well as in

\footnotetext{
9 Verkhovna Rada of Ukraine. (1996). Constitution of Ukraine: Law of Ukraine of June 28, 1996 [online] Available at: https://zakon.rada.gov.ua/laws/show/254\%D0\%BA/96-\%D0\%B2\%D1\%80 [Accessed 15 Aug. 2020].

${ }^{10} \mathrm{Id}$.

11 Stefanchuk R. (2005). Civil Law of Ukraine. Kyiv: Pretsedent, 2005, p. 24.

${ }^{12}$ Punda O. (2003). The concept and content of the right to health. "Bulletin of the Khmelnytsky Institute of Regional Management and Law", $3-4$, p. 82

13 Alexiadou E.A. (2018). Ethnic Diversity and Access to Healthcare from a Human Rights Perspective: The Case of the Roma in Europe. "European journal of health law", 25(3), pp. 261-283. DOI: 10.1163/15718093-12530367

14 Bihun V. (2009). Judicial understanding of law in the mechanism of human rights [online] Available at: http://bihun.in.ua/jushits/jurhit/article/632/

${ }^{15}$ Verkhovna Rada of Ukraine. (1993). Fundamentals of the legislation of Ukraine on health care: Law of Ukraine of November 19, 1992. Vidomosti of the Verkhovna Rada of Ukraine, 4, Art. 19.

${ }^{16}$ Vitkova V. (2014). The right to medical care and the right to die (euthanasia). "Legal Bulletin", 6, pp. 356-361.

${ }^{17}$ Lehan V., Ginzburg V., Kryachkova L. \& Borvinko E. (2014). Upgrading secondary care is a way to improve health care efficiency. "Bulletin of problems of biology and medicine", 3, pp. 201-205.

${ }^{18}$ Cabinet of Ministers of Ukraine. (2002). On approval of the Program for providing citizens with state-guaranteed free medical care: Resolution of the Cabinet of Ministers of Ukraine of July 11, 2002 [online] Available at: https://zakon.rada.gov.ua/laws/show/9552002-\%D0\%BF\#Text Accessed 15 Aug. 2020].

19 Antonov S. (2009). Legal regulation of medical services. "Health Facility Management", 2, p. 20.
} 
connection with pregnancy and childbirth"20.

In the Ukrainian doctrine you can find various definitions of the concept of the "right to medical care". For example, S. Stetsenko emphasizes that according to Article 49 of the Constitution of Ukraine citizens are guaranteed the right to medical care, which in contrast to the broader concept of the right on health protection, is an individual approach and is just a part of the health care system ${ }^{21}$. Z. Skaletska considers that the right to medical care is a special legal guarantee of the right to health protection, as it ensures the restoration of health ${ }^{22}$. According to Z. Kameneva, the right to medical care should be understood as the right to demand from a medical institution or medical organization the actions provided by law in order to preserve, strengthen, treat, restore physical or mental health ${ }^{23}$.

In general, the content of the right to medical care can be characterized as the ability of a person to receive professional qualified care to diagnose health, prevention and treatment of certain health disorders ${ }^{24}$.

In legal doctrine, there are quite different approaches to understanding the content of the right to medical care ${ }^{25}$. Thus, I. Senyuta considers the content of the right to medical care in conjunction with the content of the right to health protection. He notes, that the content of the right to health protection and medical care is a set of individual powers to improve and maintain health as a major socio-economic good to the conditions necessary for the formation of a healthy lifestyle, timely provision of preventive and rehabilitation measures aimed at maintaining and strengthening health ${ }^{26}$.

Ya. Arkatov considers the content of the right to medical care as a set of powers of a person, which is established and protected by the state and expressed in the ability to receive qualified diagnostic examination, treatment, rehabilitation therapy and preventive measures in the treatment, taking into account the volume of free medical care guaranteed by the Constitution and the legislation in state and municipal health care institutions ${ }^{27}$.

However, the most substantiated and meaningful is the scientific position of S. Buletsa, who considers the content of the constitutional right to medical care through the prism of the construction of the content of subjective right, which has developed in the theory of $\mathrm{law}^{28}$. The researcher notes that the processes of implementation, protection and defense of the right to affordable and quality medical care between the patient, health care provider and medical organization can take place in a regulatory and protective relationship ${ }^{29}$.

It should also be noted regarding the distinction between "medical care" and "medical service". The Decision of the Constitutional Court of Ukraine (the case of free medical care) states that the term medical care is widely used in the national legislation of Ukraine, there are certain definitions of the WHO, scientists, medical universities and academies. But there is no holistic legal definition of this concept in the laws of Ukraine, and therefore this requires regulation. According to the Constitutional Court of Ukraine, the concept should be defined in law ${ }^{30}$. In addition, another term is used - medical service, which is also not defined. As noted in the Decision of the Constitutional Court of Ukraine (the case of paid medical services), the meaning of the term "medical service" is close to medical care, but still remains undefined at the legislative level ${ }^{31}$.

Taking into account the above normative-legal and doctrinal approaches to the definition of "the right to medical

${ }^{20}$ Verkhovna Rada of Ukraine. (1993). Fundamentals of the legislation of Ukraine on health care: Law of Ukraine of November 19, 1992. Vidomosti of the Verkhovna Rada of Ukraine, 4, Art. 19.

${ }^{21}$ Stetsenko S. (2010). Medical law of Ukraine (realization and protection of patients' rights). Kyiv: Attica, 2010, p. 20.

${ }^{22}$ Skaletska Z. (2009). The relationship between the right to health protection and the right to medical care. "Scientific notes", 90, p. 91-93.

${ }^{23}$ Kameneva Z. (2004). The concept and content of the right of citizens to medical care. "Attorney", 7, p. 17-21.

${ }^{24}$ De Barcellos A.P., Souza F., De Mello H.L., Florentino J., De Souza S. \& Bianco T. (2017). Right to healthcare and priorities: introduction to inevitable debate. "Revista diretio GV", 13(2), pp. 504-530. DOI: 10.1590/2317-6172201718

${ }^{25}$ Grevtsova R. (2015). Current issues of legal regulation of public health in Ukraine. Administrative Law and Procedure, 1 (11), p. 195-208.

${ }^{26}$ Senyuta I. (2009). Patients' rights in the decisions of the European Court of Human Rights. Visnyk of Lviv National University, 48, p. 1320.

${ }^{27}$ Arkatov Ya. (2012). Regarding the content of the right to medical care. "Development of labor and social security legislation: achievements and problems". Kharkiv: Pravo, 2012, p. 475-478.

${ }^{28}$ Buletsa S., Deshko L. \& Zaborovskyy V. (2019). The peculiarities of changing health care system in Ukraine. "Medicine and law", 38(3), pp. 427-441.

${ }^{29}$ Buletsa S. (2015). Civil law relations in the field of medical activity: problems of theory and practice, Uzhgorod: Lira, 2015 , p. 72.

${ }^{30}$ Constitutional Court of Ukraine. (2002). Judgment of the Constitutional Court of Ukraine (free medical care case) of May 29, 2002. "Official Gazette of Ukraine", 23, Art. 107.

${ }^{31}$ Constitutional Court of Ukraine. (1998). Judgment of the Constitutional Court of Ukraine (cases on paid medical services) of November 28 , 1998. "Official Gazette of Ukraine", 50, Art. 119. 
care", in our opinion, the right of an individual to medical care can be defined as the right to receive a set of treatment and prevention measures for healthy and sick people in order to preserve and restore their health within public, municipal and private medical institutions to persons with medical (higher or secondary) education.

In our view, the concept of the right to health protection is broader than the right to medical care and encompasses the latter.

The analysis of the constitutional norms on the right of a person to health protection allows to single out the following constituent elements of the content of this right:

1) the right to health protection and qualified medical care;

2) the right to security;

3) the right to medical secrecy;

4) the right to consent to medical intervention and refusal of medical intervention;

5) the right to compensation for damage caused to health;

6) the right to innovation (medical and biological experiment, reproductive technologies, donation, therapeutic cloning, gender reassignment);

7) the right to freedom of choice in the field of health care (free choice of doctor, means of treatment, health care institution, treatment abroad, etc.). ${ }^{32}$

In turn, the content of the right of an individual to medical care is a set of human capabilities in the manner and within the limits prescribed by law, free of charge in health care institutions, regardless of its form of ownership and legal form, medical care, which includes:

1) emergency medical care;

2) primary care ${ }^{33}$;

3) secondary (specialized) medical care provided on medical grounds in accordance with the procedure established by the central executive body, which ensures the formation of state policy in the field of health protection;

4) tertiary (highly specialized) medical care provided on medical grounds in the manner prescribed by the central executive body, which ensures the formation of state policy in the field of health protection;

5) palliative care provided on medical grounds in accordance with the procedure established by the central executive body, which ensures the formation of state policy in the field of health protection.

\subsection{Peculiarities of Exercising the Right to Health Protection and Medical Care during the Pandemic COVID-19}

Given the large number of international regulations defining guarantees of the right to health protection and medical care, as well as strong guarantees at the level of the Constitution of Ukraine, the question arises whether these rights can be limited, even in an emergency such as a pandemic. The need to reconcile private and public interests and find a balance between them is one of the "eternal problems", which has faced each country since the emergence of the state form of social community. In the XX century, when the fundamental rights and freedoms of the individual were internationally recognized and legalized, one of the most acute aspects of the problem of reconciling interests was the issue of the admissibility of limiting human rights and freedoms in order to protect public and state interests. Sometimes protection of the rights of some people may cause restriction on rights of other people, and such situation is possible in extreme cases such as pandemic. Thus, human rights may be restricted in order to protect interests of other people, but there should be good enough reasons for the restrictions ${ }^{34}$. This fundamental principle of the rule of law is reflected in the Convention for the Protection of Human Rights and Fundamental Freedoms (hereinafter - the Convention). Namely, Articles 8, 9, 10 and 11 of the Convention provide for interference with fundamental rights where it is necessary in a democratic society to protect health.

Article 15 of the Convention also derogates from certain rights, indicating that "in time of war or other public emergency threatening the life of the nation any High Contracting Party may take measures derogating from its

\footnotetext{
32 Shvets Yu. (2017). Contents of the constitutional right to health care. "Entrepreneurship, Economy and Law", 8, p. 135-138.

${ }^{33}$ Morandi S., Silva B., Bonsack C. \& Golay P. (2020). Propensity to decide on involuntary hospitalisation in primary medical care: Dispositional or situational determinants? "International journal of law and psychiatry", 69, Article Number 101552. DOI: 10.1016/j.ijlp.2020.101552

${ }^{34}$ Greer S.L. \& Sokol T. (2014). Rules for Rights: European Law, Health Care and Social Citizenship. "European law journal”, 20(1), pp. 6687. DOI: $10.1111 /$ eulj.12036
} 
obligations under this Convention to the extent strictly required by the exigencies of the situation, provided that such measures are not inconsistent with its other obligations under international law". ${ }^{35}$

First of all, the response of the state during an emergency should be based on factual data, and not due to political pressure or the need to do something ${ }^{36}$. There must be a clear scientific and medical justification for emergency measures. No less important is the need to use the legislation to achieve the ultimate goal. It is necessary to prove that the recommendations, soft commitments and restrictive measures will not work and the enforcement of a quality law is necessary.

The European Court of Human Rights (hereinafter - the ECtHR) in its explanations on the application of Art. 15 of the Convention stated that due attention was paid to such factors as: the nature of the rights affected by the waiver, the circumstances giving rise to the emergency and its duration (Brannigan and McBride v. the United Kingdom ${ }^{37}$ ); whether ordinary legislation would be sufficient to deal with the threat posed by public danger; whether the measures are a valid response to the emergency; whether the measures were used for the purpose for which they were authorized; whether safeguards against abuse were provided ${ }^{38}$.

In addition, human rights guarantees under international standards must be maintained during the pandemic COVID-19.

Thus, the European Social Charter (hereinafter - the Charter) establishes a wide range of rights that are affected directly and indirectly by the pandemic COVID-19. First, it provides for the right to health protection in the context of Article 11 of the Charter, which requires States "to prevent as far as possible epidemic, endemic and other diseases, as well as accidents". Article 13 of the Charter enshrines the right to social and medical assistance, which clearly states that States must guarantee the provision of adequate assistance to any low-income person and, most importantly, in the case of illness, the provision of the care required by his or her state of health. ${ }^{39}$ And this obviously applies to situations where the disease is caused by the COVID-19. The impact of the COVID-19 pandemic on different populations and government efforts to stop the spread of the virus can vary widely.

The Charter provides for a very broad list of responsibilities of the state in a pandemic. Thus, Article 11 establishes the right of everyone to enjoy any measures that allow them to maintain the highest attainable standard of health. This means that during the COVID-19 pandemic, States must take all possible measures to ensure that everyone is able to maintain the highest attainable standard of health, and that public policy, laws and resources must be aimed at this. COVID-19 requires careful, reasonable and effective preventive measures that do not contradict the exercise of the right to health protection.

The Charter also provides for the need to ensure support to the most vulnerable groups during the COVID-19 pandemic. The Charter requires States to take measures to meet the needs and rights of persons with disabilities, children and the elderly, and to ensure that governments pay special attention to their rights in the context of measures to combat the COVID-19 virus. But there are other vulnerable groups that do not need to be directly mentioned in the Charter, but also need special attention. For example, homeless people or prisoners. Also people who are in an uncertain state of migration. It is interesting to note that the Charter itself states that the right to health care, as well as a number of other key rights of the Charter, apply only to foreigners, provided that they are citizens of other states that have ratified the Charter and legally and permanently reside or work in the territory of the State Party concerned. At first glance, this means that the Charter does not cover particularly vulnerable groups, such as unaccompanied minors or migrants who do not have identity documents. However, in reality, this part of the Charter cannot be taken in this sense, as it deprives migrants who are in an uncertain migratory state of protection. In addition, the fundamental rights enshrined in the Charter cannot be interpreted in such a way as to undermine their fundamental rights, such as the right to life, physical integrity or human dignity ${ }^{40}$.

\footnotetext{
${ }^{35}$ European Court of Human Rights, Council of Europe. (1950). Convention for the Protection of Human Rights and Fundamental Freedoms. [online] Available at: https://www.echr.coe.int/Documents/Convention_ENG.pdf [Accessed 15 Aug. 2020].

${ }^{36}$ Agarwal V. \& Ganesh L. (2020). Standards of human rights to palliative care: gaps and trends. "International journal of human rights in health care", Vol. ahead-of-print, No. ahead-of-print. [online] Available at: https://doi.org/10.1108/IJHRH-02-2020-0013 [Accessed 5 Aug. 2020].

${ }^{37}$ European Court of Human Rights. (1993). Case of Brannigan and McBride v. the United Kingdom (Application no. 14553/89; 14554/89). [online] Available at: https://hudoc.echr.coe.int/fre\#\{\%22itemid\%22:[\%22001-57819\%22]\} [Accessed 15 Aug. 2020].

38 Krivorot V., Martynenko A. (2020). Human rights interference during a pandemic [online] Available at: https://protocol.ua/ua/vtruchannya_v_prava_lyudini_pid_chas_pandemii/ [Accessed 15 Aug. 2020].

${ }^{39}$ Council of Europe. (1996). European Social Charter. [online] Available at: https://rm.coe.int/168007cf93 [Accessed 10 Aug. 2020].

${ }^{40}$ Nolan I. (2020). COVID-19 requires careful, reasonable and effective preventive measures that do not contradict the exercise of the right to health protection [online] Available at: http://www.nrcu.gov.ua/news.html?newsID=93302 [Accessed 15 Aug. 2020].
} 
To ensure that human rights are properly respected, Ukraine must ensure that all health care services provided in connection with coronavirus are provided without any discrimination, and make it clear to the public that everyone has the right to access medical care.

Authorities should take steps to establish information filters between undocumented health workers and undocumented migrants so that they do not fear deportation and sanctions and seek medical attention ${ }^{41}$.

In order to fully exercise the right to health, it is important to take the necessary measures to create conditions that would provide all citizens, in the first place, with medical care in the event of illness. This means minimizing the risk of occupational injuries and diseases, including providing workers with health information, appropriate protective clothing and equipment ${ }^{42}$.

In addition, Ukraine must take measures to ensure that health care is accessible to all, including financially, without discrimination and with respect for medical ethics and respect for cultural characteristics, and that medical services are of adequate quality, and that health workers have access to appropriate remedies and that relatives of the dead have access to social support programs.

\subsection{Some Issues of Personal Data Protection in the Sphere of the Health Protection in Terms of the Pandemic COVID-19}

It is important to pay attention to the processing of personal data and to determine whether the processing of personal data in terms of the pandemic COVID-19 violates human rights.

In Ukraine, in the context of the pandemic, some legislation that often violates human rights and a lack of balance between privacy and public health is being enacted.

For example, on April 13, 2020, the Law of Ukraine "On Amendments to the Law of Ukraine "On Protection of the Population from Infectious Diseases" to Prevent the Spread of Coronavirus Disease (COVID-19)"43 was adopted. According to the above-mentioned Law, for the period of quarantine or restrictive measures related to the spread of coronavirus disease (COVID-19) and within 30 days from the date of its abolition, personal data may be processed without consent of the person. In particular it can be data concerning the state of health, place of hospitalization or self-isolation, surname, name, patronymic, date of birth, place of residence, work (study). The processing of data without consent is being performed in order to counteract the spread of coronavirus disease (COVID-19), in the manner specified in the decision to establish quarantine, provided that such data is used solely for the purpose of anti-epidemic measures. Within 30 days after the end of the quarantine period, such data shall be depersonalized and, if impossible, destroyed.

It should be noted that the Convention for the Protection of Human Rights and Fundamental Freedoms stipulates that everyone has the right to respect for someone's private and family life, home and correspondence. At the same time, the Constitution of Ukraine stipulates that no person may be interfered with in his or her personal and family life, except as provided by the Constitution of Ukraine. It is important to note that Article 64 of the Constitution of Ukraine stipulates that the constitutional rights and freedoms may not be restricted, except in cases provided by the Constitution of Ukraine. In conditions of martial law or state of emergency, certain restrictions on rights and freedoms may be established, indicating the term of these restrictions. On March 25, 2020, the Cabinet of Ministers decided to introduce a state of emergency throughout Ukraine. The Law of 13 April 2020 sets out the grounds for such an intervention to combat the spread of coronavirus disease (COVID-19).

The preamble to the above-mentioned Law of Ukraine "On Protection of the Population from Infectious Diseases" $" 44$ stipulates that it defines the legal, organizational and financial principles of activity of state and local levels, enterprises, institutions and organizations aimed at preventing the spread of infectious diseases, localization and elimination of outbreaks and epidemics, establishes the rights, duties and responsibilities of legal entities and individuals in the field of protection of the population from infectious diseases.

Therefore, the Law of Ukraine "On Personal Data Protection" regulates legal relations related to the processing of personal data, and the Law of Ukraine "On Protection of the Population from Infectious Diseases" should regulate

${ }^{41}$ Davenport K. (2020). Life in the law in the time of COVID-19 - a view from the middle. "Australian law journal", 94(7), pp. 481-487.

42 Goodale M. (2020). The UN at 75: Human rights and global pandemic. "Netherlands quarterly of human rights", 38(3). [online] Available at: https://www.researchgate.net/publication/341234542_The_UN_at_75_Human_rights_and_global_pandemic [Accessed 5 Aug. 2020].

${ }^{43}$ Verkhovna Rada of Ukraine. (2020). On Amendments to the Law of Ukraine "On Protection of the Population from Infectious Diseases" to Prevent the Spread of Coronavirus Disease (COVID-19): Law of Ukraine of April 13, 2020. [online] Available at: https://zakon.rada.gov.ua/laws/show/555-20\#Text [Accessed 15 Aug. 2020].

${ }^{44}$ Verkhovna Rada of Ukraine. (2020). On protection of the population from infectious diseases: Law of Ukraine of April 6, 2020.[online] Available at: https://zakon.rada.gov.ua/laws/show/1645-14/card2\#Text [Accessed 15 Aug. 2020]. 
only the rights of individuals in the field of protection against infectious diseases. In this context, the question arises: why have no changes been made to the processing of personal data in the special Law governing the protection of personal data, and in general, what are the legal grounds for the limitation of such constitutional right in an emergency?

According to Art. 2 of the Law of Ukraine "On Personal Data Protection", personal data is information or a set of information about an individual who is identified or can be specifically identified ${ }^{45}$. According to Art. 21 of the Law of Ukraine "On Information", information about an individual (personal data) is information or a set of information about an individual who is identified or can be specifically identified ${ }^{46}$.

Thus, it can be argued that the processing of personal data is allowed solely for the purpose of anti-epidemic measures.

In accordance with Art. 1 of the Law of Ukraine "On Protection of the Population from Infectious Diseases", antiepidemic measures are a set of organizational, health, veterinary, engineering, administrative and other measures taken to prevent the spread of infectious diseases, localization and elimination of their hotbeds, outbreaks and epidemics. Therefore, it is impossible to clearly determine who has the right to process the mentioned data, as there is no clear list of subjects. If you interpret the rule literally, such a list should be sought in the decision to establish quarantine. If we analyze the definition of "quarantine", which is enshrined in Art. 1 of the Law of Ukraine "On Protection of the Population from Infectious Diseases", such measures should include only administrative and health.

The procedure of data processing, namely the collection, registration, accumulation, storage, adaptation, modification, renewal, use and dissemination, depersonalization, destruction of personal data, attracts attention ${ }^{47}$. However, it is not clear which group of persons will be subject to such forced data processing (only those with COVID-19, contact persons or anyone in general).

If you interpret the rule literally, it turns out that the decision on quarantine applies to every person. Therefore, it is important to determine the amount of data to be processed ${ }^{48}$. This list is not exhaustive, but it is determined that it includes such data as: health status; place of hospitalization or self-isolation; Full Name; date of birth; residence; work (study).

However, it remains unclear for what purpose such restrictions are imposed if consent to the processing of personal data was not required in cases where such information is necessary for health protection, medical diagnosis, care or treatment or the provision of medical services, functioning of the electronic health care system, provided that such data are processed by an authorized entity (medical worker, individual entrepreneur who has received a license in the manner prescribed by law, etc.), which is responsible for ensuring the protection of personal data and which is covered by laws and other regulations on medical secrecy.

Therefore, healthcare professionals should not consent to the processing of their patients' personal data, as such processing is carried out in accordance with the provisions of the law. Therefore, in Ukraine the form "Informed voluntary consent of the patient to the processing of personal data" has been abolished, and the transfer of personal data to a third party should not be reported by the owner if the transfer is carried out by state and local governments.

\section{Conclusions}

1) In Ukraine, there is still no basic legislation that defines the most important areas of health care development at the present stage. Currently, issues of health protection are regulated by the Constitution of Ukraine, the Civil Code of Ukraine, the Fundamentals of Legislation of Ukraine on Health Care and numerous bylaws. On the one hand, in these regulations, there is a certain imperfection, and in some cases, the conflict of laws, on the other hand, there is a duplication of system-wide and basic laws in bylaws.

2) A significant problem remains the legal provision of quality control of medical care, the creation of organizational technologies with a clear division of control functions between the various actors in the health care

\footnotetext{
45 Verkhovna Rada of Ukraine. (2010). On personal data protection: Law of Ukraine of June 1, 2010. [online] Available at: https://zakon.rada.gov.ua/laws/show/2297-17 [Accessed 15 Aug. 2020].

46 Verkhovna Rada of Ukraine. (1992). On information: Law of Ukraine of October 2, 1992. [online] Available at: https://zakon.rada.gov.ua/laws/show/2657-12

${ }^{47}$ Gutierrez A.M., Hofstetter J. D., Dishner E. L., Chiao E., Rai D. \& McGuire A. L. (2020). A Right to Privacy and Confidentiality: Ethical Medical Care for Patients in United States Immigration Detention. "Journal of law medicine \& ethics", 48(1), pp. 161-168.DOI: $10.1177 / 1073110520917004$

${ }^{48}$ Malgieri G. (2020). Data protection and research: A vital challenge in the era of COVID-19 pandemic. "Computer law \& security review", 37. [online] Available at: https://www.ncbi.nlm.nih.gov/pmc/articles/PMC7151303/ doi: 10.1016/j.clsr.2020.105431 [Accessed 5 Aug. 2020].
} 
system. No less important is the problem of developing clear and specific mechanisms to protect the rights and interests of patients in providing them with medical care, the responsibility of medical organizations for the volume and quality of medical care.

3) Restrictions on human rights to health and health protection established in the context of the pandemic COVID19 are generally permissible in the light of international standards. However, the restrictions imposed in Ukraine are not commensurate with the existing terms, as the legislative provisions existed before the pandemic were enough to counteract the spread of coronavirus disease (COVID-19) in the studied aspect.

4) In order to properly respect the rights to health protection and medical care, a number of conditions must be met:

- surveillance measures taken to combat COVID-19 must be lawful, necessary and proportionate;

- Ukraine should follow the principles of transparency regarding the measures taken in order to study them and, if necessary, amend, revoke or repeal them;

- in the case of increased powers to monitor and observe citizens and involve artificial intelligence ${ }^{49}$, the risk of discrimination and other human rights violations, whose needs or living conditions may be insufficiently represented or distorted in large databases, should be taken into account and data sharing agreements should be in public access;

- any measures should include mechanisms for reporting and protecting against abuse, and citizens should in turn be able to be aware of the list of restrictive measures and be able to challenge any COVID-19-related measures for the collection, aggregation, storage and further use of their data.

5) Provisions of the current legislation of Ukraine in the field of medicine do not provide proper regulation of relations regarding the provision of medical services, do not establish guarantees for the protection of the rights and interests of patients. There is no definition of the term "medical service", quality standards for medical services are not adopted, the liability of doctors and medical institutions for non-provision or poor quality of medical services are regulated inconsistently and ambiguously both at the level of theory and case law. It should be noted the fragmentary nature of the study of personal data protection, as well as the conclusion of electronic contracts in the field of medical law. Therefore, there is an urgent need to bring medical legislation in line with today's requirements.

\section{References}

Agarwal, V., \& Ganesh, L. (2020). Standards of human rights to palliative care: gaps and trends. International journal of human rights in health care. https://doi.org/10.1108/IJHRH-02-2020-0013

Alexiadou, E. A. (2018). Ethnic Diversity and Access to Healthcare from a Human Rights Perspective: The Case of the Roma in Europe. European journal of health law, 25(3), 261-283. https://doi.org/10.1163/1571809312530367

Antonov, S. (2009). Legal regulation of medical services. "Health Facility Management", 2, p. 20.

Arkatov, Ya. (2012). Regarding the content of the right to medical care. Development of labor and social security legislation: achievements and problems. Kharkiv: Pravo.

Bihun, V. (2009). Judicial understanding of law in the mechanism of human rights. Retrieved from http://bihun.in.ua/jushits/jurhit/article/632/

Buletsa, S. (2015). Civil law relations in the field of medical activity: problems of theory and practice. Uzhgorod: Lira.

Buletsa, S., Deshko, L., \& Zaborovskyy, V. (2019). The peculiarities of changing health care system in Ukraine. Medicine and law, 38(3), 427-441.

Cabinet of Ministers of Ukraine. (2002). On approval of the Program for providing citizens with state-guaranteed free medical care: Resolution of the Cabinet of Ministers of Ukraine of July 11, 2002. Retrieved August 15, 2020, from https://zakon.rada.gov.ua/laws/show/955-2002-\%D0\%BF\#Text

Cabinet of Ministers of Ukraine. (2020). On prevention of the spread of acute respiratory disease COVID-19 caused by coronavirus SARS-CoV-2 on the territory of Ukraine: Resolution of the Cabinet of Ministers of

${ }^{49}$ Nekit K., Kolodin D. \& Fedorov V. (2020). Personal data protection and liability for damage in the field of the Internet of Things. "Juridical Tribune", 10(1), pp. 80-93. 
Ukraine of March 11, 2020. Retrieved August 15, 2020, from https://zakon.rada.gov.ua/laws/show/211$2020-\% \mathrm{D} 0 \% \mathrm{BF} \# \mathrm{Text}$

Constitutional Court of Ukraine. (1998). Judgment of the Constitutional Court of Ukraine (cases on paid medical services) of November 28, 1998. "Official Gazette of Ukraine", 50, Art. 119.

Constitutional Court of Ukraine. (2002). Judgment of the Constitutional Court of Ukraine (free medical care case) of May 29, 2002. "Official Gazette of Ukraine", 23, Art. 107.

Council of Europe. (1996). European Social Charter. Retrieved August 10, 2020, from https://rm.coe.int/168007cf93

Davenport, K. (2020). Life in the law in the time of COVID-19 - a view from the middle. Australian law journal, 94(7), 481-487.

De Barcellos, A. P., Souza, F., De Mello, H. L., Florentino, J., De Souza, S., \& Bianco, T. (2017). Right to healthcare and priorities: introduction to inevitable debate. Revista diretio GV, 13(2), 504-530. https://doi.org/10.1590/2317-6172201718

European Court of Human Rights, Council of Europe. (1950). Convention for the Protection of Human Rights and Fundamental Freedoms. Retrieved August 15, 2020, from https://www.echr.coe.int/Documents/Convention_ENG.pdf

European Court of Human Rights. (1993). Case of Brannigan and McBride v. the United Kingdom (Application no. 14553/89; 14554/89). Retrieved August 15, 2020, from https://hudoc.echr.coe.int/fre\#\{\%22itemid\%22:[\%22001-57819\%22]\}

Goodale, M. (2020). The UN at 75: Human rights and global pandemic. Netherlands quarterly of human rights, 38(3). https://doi.org/10.1177/0924051920943492

Greer, S. L., \& Sokol, T. (2014). Rules for Rights: European Law, Health Care and Social Citizenship. European law journal, 20(1), 66-87. https://doi.org/10.1111/eulj.12036

Grevtsova, R. (2015). Current issues of legal regulation of public health in Ukraine. Administrative Law and Procedure, 1(11), 195-208.

Gutierrez, A. M., Hofstetter, J. D., Dishner, E. L., Chiao, E., Rai, D., \& McGuire, A. L. (2020). A Right to Privacy and Confidentiality: Ethical Medical Care for Patients in United States Immigration Detention. Journal of law medicine \& ethics, 48(1), 161-168. https://doi.org/10.1177/1073110520917004

Kameneva, Z. (2004). The concept and content of the right of citizens to medical care. Attorney, 7, 17-21.

Krivorot, V., \& Martynenko, A. (2020). Human rights interference during a pandemic. Retrieved August 15, 2020, from https://protocol.ua/ua/vtruchannya_v_prava_lyudini_pid_chas_pandemii/

Lehan, V., Ginzburg, V., Kryachkova, L., \& Borvinko, E. (2014). Upgrading secondary care is a way to improve health care efficiency. Bulletin of problems of biology and medicine, 3, 201-205.

Malgieri, G. (2020). Data protection and research: A vital challenge in the era of COVID-19 pandemic. Computer law \& security review, 37. https://doi.org/10.1016/j.clsr.2020.105431

Morandi, S., Silva, B., Bonsack, C., \& Golay, P. (2020). Propensity to decide on involuntary hospitalisation in primary medical care: Dispositional or situational determinants? International journal of law and psychiatry, 69. https://doi.org/10.1016/j.ijlp.2020.101552

Nekit, K., Kolodin, D., \& Fedorov, V. (2020). Personal data protection and liability for damage in the field of the Internet of Things. Juridical Tribune, 10(1), 80-93.

Nolan, I. (2020). COVID-19 requires careful, reasonable and effective preventive measures that do not contradict the exercise of the right to health protection. Retrieved August 15, 2020, from http://www.nrcu.gov.ua/news.html?newsID=93302

Punda, O. (2003). The concept and content of the right to health. Bulletin of the Khmelnytsky Institute of Regional Management and Law, 3-4, 82.

Senyuta, I. (2009). Patients' rights in the decisions of the European Court of Human Rights. Visnyk of Lviv National University.

Shvets, Yu. (2017). Contents of the constitutional right to health care. Entrepreneurship, Economy and Law, 8, 135-138. 
Skaletska, Z. (2009). The relationship between the right to health protection and the right to medical care. Scientific notes, 90, p. 91-93.

Stefanchuk, R. (2005). Civil Law of Ukraine. Kyiv: Pretsedent.

Stetsenko, S. (2010). Medical law of Ukraine (realization and protection of patients' rights). Kyiv: Attica.

USLegal. (2020). Quarantine Law and Legal Definition. Retrieved August 27, 2020, from https://definitions.uslegal.com/q/quarantine/

Verkhovna Rada of Ukraine. (1992). On information: Law of Ukraine of October 2, 1992. Retrieved from https://zakon.rada.gov.ua/laws/show/2657-12

Verkhovna Rada of Ukraine. (1993). Fundamentals of the legislation of Ukraine on health care: Law of Ukraine of November 19, 1992. Vidomosti of the Verkhovna Rada of Ukraine, 4, Art. 19.

Verkhovna Rada of Ukraine. (1996). Constitution of Ukraine: Law of Ukraine of June 28, 1996. Retrieved August 15, 2020, from https://zakon.rada.gov.ua/laws/show/254\%D0\%BA/96-\%D0\%B2\%D1\%80

Verkhovna Rada of Ukraine. (2010). On personal data protection: Law of Ukraine of June 1, 2010. Retrieved August 15, 2020, from https://zakon.rada.gov.ua/laws/show/2297-17

Verkhovna Rada of Ukraine. (2020). On Amendments to the Law of Ukraine "On Protection of the Population from Infectious Diseases" to Prevent the Spread of Coronavirus Disease (COVID-19): Law of Ukraine of April 13, 2020. Retrieved August 15, 2020, from https://zakon.rada.gov.ua/laws/show/555-20\#Text

Verkhovna Rada of Ukraine. (2020). On protection of the population from infectious diseases: Law of Ukraine of April 6, 2020. Retrieved August 15, 2020, from https://zakon.rada.gov.ua/laws/show/1645-14/card2\#Text

Vitkova, V. (2014). The right to medical care and the right to die (euthanasia). "Legal Bulletin", 6, pp. 356-361.

\section{Copyrights}

Copyright for this article is retained by the author(s), with first publication rights granted to the journal.

This is an open-access article distributed under the terms and conditions of the Creative Commons Attribution license (http://creativecommons.org/licenses/by/4.0/). 